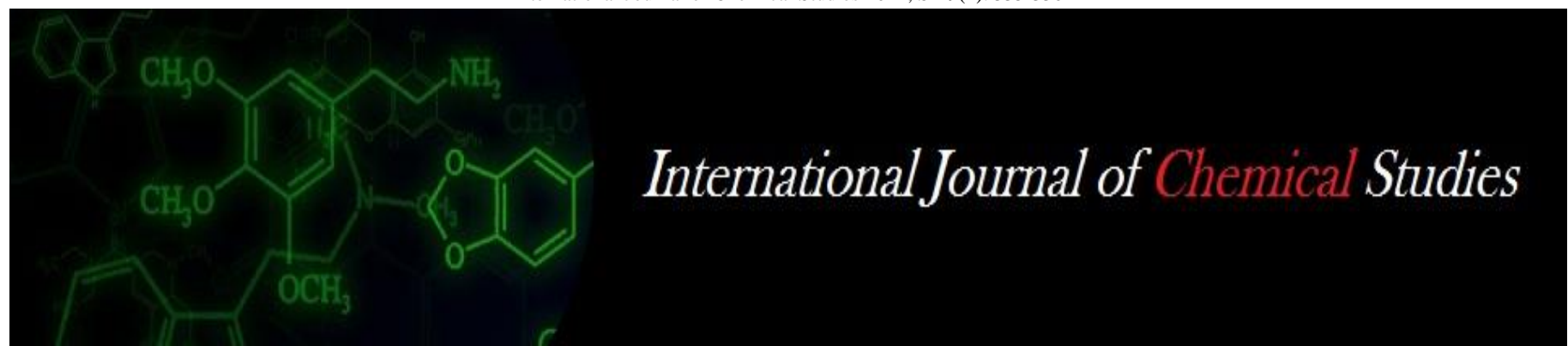

P-ISSN: 2349-8528

E-ISSN: 2321-4902

www.chemijournal.com

IJCS 2021; SP-9(1): 335-336

(C) 2021 IJCS

Received: 08-10-2020

Accepted: 19-12-2020

\section{Rohit Meena}

Department of Livestock

Products Technology, College of

Veterinary and Animal Science,

Bikaner, Rajasthan, India

\section{Basant Bais}

Department of Livestock

Products Technology, College of

Veterinary and Animal Science,

Bikaner, Rajasthan, India

\section{Lokesh Tak}

Department of Livestock

Products Technology, College of

Veterinary and Animal Science,

Bikaner, Rajasthan, India

\section{Jorawar Singh}

Department of Livestock

Products Technology, College of

Veterinary and Animal Science,

Bikaner, Rajasthan, India

Nitesh Chand Sharma

Department of Livestock

Products Technology, College of

Veterinary and Animal Science,

Bikaner, Rajasthan, India

Yogendra Singh

Department of Livestock

Products Technology, College of

Veterinary and Animal Science,

Bikaner, Rajasthan, India

\section{A study on determination of physicochemical properties of sheep and camel milk reared in arid zone of Rajasthan}

\author{
Rohit Meena, Basant Bais, Lokesh Tak, Jorawar Singh, Nitesh Chand \\ Sharma and Yogendra Singh
}

DOI: https://doi.org/10.22271/chemi.2021.v9.i1f.11834

\begin{abstract}
Milk is highly nutritious and supplies body building proteins, bone forming minerals, healthful vitamins and provide energy giving lactose and milk fat. Sheep milk has high nutritional value and high concentrations of proteins, fats, minerals, and vitamins as compared to the milk of other domestic species. The high levels of protein, fat, and calcium make it an excellent matrix for cheese production. Sheep milk proteins are also important sources of bioactive ACE inhibitory peptides and antihypertensive peptides. They can protect and control microbial infections against non-immune diseases. The activity of these biofunctional peptides is based on their composition and sequence of amino acids. Camel milk is unique in terms of having low fat (1.5-3\%) and low protein $(2.5 \%)$. Camel milk is known for its medicinal properties, which are widely exploited for human health. The low quantity of $\beta$-casein and the lack of $\beta$-lactoglobulin are linked to the hypo-allergic effect of camel milk. Other components such as lactoferrin, immunoglobulin, lysozyme or vitamin $\mathrm{C}$ were reported to play a central role in the determination of these properties. In the present investigation an attempt was made to evaluate the physicochemical properties of sheep and camel milk as well as admixture of sheep and camel milk.
\end{abstract}

Keywords: Determination, physicochemical, sheep, camel milk

\section{Introduction}

At present, India is the world's largest milk producer now reaching a level of about 163.7 million tones with an annual growth rate of $5.53 \%$. Out of the total production $46 \%$ milk is consumed in liquid form; $54 \%$ is utilized for manufacturing of different milk products and $3 \%$ is utilized for channa and paneer production.

The physicochemical and nutritional characteristics of sheep milk can be advantageous for the manufacture of products containing prebiotic ingredients and probiotic bacteria, which are major categories in the functional food market. The high protein and overall solid contents of sheep milk make it particularly appropriate for cheese and yoghurt making. Sheep milk contains one and half times more protein than cow milk (up to 6-7\%), and has more A, B1 and B12 vitamins. Sheep milk is an important attribute of food of many nations in Europe Asia and the Middle East. Mostly the milk products such as yogurt, kefir, cheese, butter are made from sheep milk. It also has simple lipids (diacylglycerols, monoacylglycerols, and cholesterol esters), complex lipids (phospholipids), and liposoluble compounds (sterols, cholesterol esters, hydrocarbons) Sheep colostrum is also higher in basic nutrients than cow colostrum in the early postpartum 2 period: fat $13.0 \%$ and $5.1 \%$ protein $11.8 \%$ and $7.1 \%$, lactose $3.3 \%$ and $3.6 \%$, minerals $0.9 \%$ and $0.9 \%$ total solids $28.9 \%$ and $15.6 \%$ respectively.

Camel milk is unique in terms of having low fat (1.5-3\%) and low protein $(2.5 \%)$. Camel milk is known for its medicinal properties, which are widely exploited for human health, as in several countries from the ex-Soviet Union and developing countries. Camel milk is considered to have anticancerous, hypo-allergic and antidiabetic properties. A high content in unsaturated fatty acids contributes to its overall dietary quality. The low quantity of $\beta$-casein and the lack of $\beta$-lactoglobulin are linked to the hypo-allergic effect of camel milk. Other components such as lactoferrin, immunoglobulin, lysozyme or vitamin $\mathrm{C}$ were reported to play a central role in the determination of these properties.

\section{Rohit Meena}

Department of Livestock Products Technology, College of Veterinary and Animal Science, Bikaner, Rajasthan, India 


\section{Material and Method}

Physicochemical properties of Sheep and camel milk

Fresh sheep milk was collected from CSWRI- Central Sheep and Wool Research Institute Bikaner and fresh camel milk was collected from camel dairy maintained at ICAR-NRC on Camel, Bikaner. All samples were collected manually in sterile bottles and were kept under chilled condition till further use. Milk samples were analyzed for $\mathrm{pH}$, SNF, fat, protein, lactose etc. using Milkoscan at Department of Livestock Products Technology, College of Veterinary and Animal Science, Rajasthan University of Veterinary and Animal Sciences, Bikaner (Rajasthan), The mean values of physicochemical properties of fresh sheep and camel milk has been presented in Table 1.

\section{Result and Discussion}

The overall compositions of sheep and camel milk was revealed that the sheep milk had higher concentrations of protein, fat and solid not fat (SNF) compared to camel milk and mixed milk.
The fat content of sheep, camel and mixed milk (30\% sheep milk and $70 \%$ camel milk) was $7.59 \pm 0.30,3.27 \pm 0.24$ and $4.87 \pm 0.18$ respectively, SNF content of sheep milk was 8.43 \pm 0.22 , for camel milk it was $7.46 \pm 0.26$, and for mixed milk it was $7.57 \pm 0.21$. Protein content of sheep, camel and mixed milk was $3.29 \pm 0.18,2.49 \pm 0.18$ and $2.50 \pm 0.16$ respectively whereas lactose content of sheep, camel and mixed was $4.49 \pm 0.18,3.85 \pm 0.22$ and $4.14 \pm 0.22$ respectively. The freezing point and $\mathrm{pH}$ of sheep, camel and mixed milk was $-0.55 \pm 0.08,-0.46 \pm 0.03,-0.47 \pm 0.06$ and $6.24 \pm 0.17,6.64 \pm 0.21,6.40 \pm 0.10$ respectively.

The dromedary camel milk protein contents range from 2.15 to $4.90 \%$ as per Konuspayeva et al. (2009) whereas the fat level of the dromedary camel varies from 1.2 to $6.4 \%$ as reported by Haddadin et al. (2008) ${ }^{[3]}$ and Konuspayeva et al. (2009). In the manufacturing of dairy products $\mathrm{pH}$ plays a significant role in determining the end product quality. The $\mathrm{pH}$ of camel milk ranged between 6.5 to 6.7 as reported by (Khaskheli et al. 2005) ${ }^{[4]}$.

Table 1: Physico-chemical properties of sheep and camel milk

\begin{tabular}{|c|c|c|c|}
\hline Physico-chemical Properties & Sheep milk (Mean \pm SE) & Camel milk (Mean \pm SE) & Sheep and Camel milk (Mean \pm SE) \\
\hline Fat \% & $7.59 \pm 0.30$ & $3.27 \pm 0.24$ & $4.87 \pm 0.18$ \\
\hline SNF \% & $8.43 \pm 0.22$ & $7.46 \pm 0.26$ & $7.57 \pm 0.21$ \\
\hline Protein \% & $3.29 \pm 0.18$ & $2.49 \pm 0.18$ & $2.50 \pm 0.16$ \\
\hline Lactose \% & $4.49 \pm 0.18$ & $3.85 \pm 0.22$ & $4.14 \pm 0.22$ \\
\hline Freezing Point $\left({ }^{0} \mathrm{C}\right)$ & $-0.55 \pm 0.08$ & $-0.46 \pm 0.03$ & $-0.47 \pm 0.06$ \\
\hline pH & $6.24 \pm 0.17$ & $6.64 \pm 0.21$ & $6.40 \pm 0.10$ \\
\hline
\end{tabular}

In general the present study showed a wide variation in the gross composition of camel milk. The results obtained for camel milk were in agreement with studies of Tak (2017) ${ }^{[7]}$, Singh (2017) ${ }^{[6]}$, and Devi (2018) ${ }^{[1]}$. This variation was concluded to be partly due to the inherited capabilities of the animals and/or attributed due to various seasonal and environmental factors as well as stage of lactation, age and number of calving. In addition, the feed and water quality and quantity available to the animals also play an important role (FAO, 1982) ${ }^{[2]}$

\section{References}

1. Devi D. Development and Quality Evaluation of Flaxseed incorporated Camel and Buffalo Milk Nuggets (M.V.Sc. thesis CVAS, RAJUVAS, Bikaner) 2018.

2. FAO. FAO Animal Production and Health Papers. Camels and Camel Milk. Food Agriculture Organization of the United Nations, Rome 1982.

3. Haddadin MS, Gammoh SI, Robinson RK. Seasonal variations in the chemical composition of camel milk in Jordan. Journal of Dairy Research 2008;75(1):8-12.

4. Khaskheli M, Arain MA, Chaudhry S, Soomro AH, Qureshi TA. Physicochemical quality of camel milk. Journal of Agriculture and Social Sciences 2005;2:164166.

5. Konuspayeva G, Lemarie É, Faye B, Loiseau G, Montet D. Fatty acid and cholesterol composition of camel's (Camelus bactrianus, Camelus dromedarius and hybrids) milk in Kazakhstan. Dairy Science and Technology 2008;88(3):327-340.

6. Singh S. The Fermentative Potential of Camel and Buffalo Milk by Using Lactococcus lactis ssp. cremoris and Lactococcus lactis ssp. Lactis. (M.V.Sc. thesis CVAS, RAJUVAS, Bikaner) 2017.
7. Tak L. The Fermentative Potential of Camel and Buffalo Milk by Using Lactobacillus fermentum and Lactobacillus helveticus. (M. V.Sc. Thesis CVAS, RAJUVAS, Bikaner) 2017. 